JPdK Volume 1 Nomor 1 Tahun 2019 Halaman 78-83 JURNAL PENDIDIKAN dan KONSELING

Research \& Learning in Faculty of Education

\title{
Analisis Keterampilan Intrapersonal Anak Usia 5-6 Tahun Di TK Negeri Pembina Kota Tasikmalaya
}

\author{
Maitsa Munifah ${ }^{1}$, Elan $^{2}$, Taopik Rahman ${ }^{3}$, Gilar Gandana ${ }^{4}$ \\ Program Guru Pendidikan Anak Usia Dini \\ Fakultas Ilmu Pendidikan \\ Universitas Pendidikan Indonesia Kampus Tasikmalaya \\ Email:maitsamunifah8243@gmail.com
}

\begin{abstract}
Abstrak
Penelitian ini didasari pentingnya keterampilan intrapersonal anak usia 5-6 tahun sebagai salah satu indikator kesuksesan individu. keterampilan intrapersonal merupakan kemampuan individu dalam memamahmi dirinya sendiri dengan kata lain anak mampu mempercayai diri sendiri, mengetahui kelebihan dan kelemahan diri sendiri, menyadari emosi yang dirasakan, serta proaktif atau bertanggung jawab terhadap pengetahuan, perasaan serta tindakannya. Ketika dilapangan peneliti menemukan deteksi keterampilan intrapersonal namun belum berlandaskan pada teori yang ideal . Dengan demikian peneliti mengambil fokus kajian pada keterampilan Intrapersonal anak usia 5-6 tahun di TK Negeri Pembina. Penelitian ini bertujuan untuk mengukur, menganalisis, serta mendeskripsikan keterampilan intrapersonal anak usia 5-6 tahun di TK Negeri Pembina Kota Tasikmalaya. Menggunakan metode deskriptif dengan pendekatan kuantitatif. Teknik pengumpulan data melalui observasi terstruktur dan catatan lapangan yang terintegrasi dalam observasi terstruktur. Temuan dalam penelitian ini bahwa keterampilan intrapersonal anak usia 5-6 tahun berada pada kategori berkembang sesuai harapan $(\mathrm{BSH})$. Keterampilan intrapersonal anak usia 5-6 tahun pada aspek percaya diri berada pada kategori berkembang sesuai harapan mendapat 62 Persen. Kemudian pada aspek penilaian diri berada pada kategori berkembang sesuai harapan dan mendapat 67 persen. Selanjutnya pada aspek kesadaran emosi anak usia 5-6 tahun berada pada kategori berkembang sesuai harapan dengan persentase 55 persen. pada aspek proaktif atau bertanggung jawab anak usia 5-6 tahun berada dalam kategori berkembang sesuai harapan dan persentase mendapat 60 persen. Dengan demikian persentase keterampilan intrapersonal anak usia 5-6 tahun di TK Negeri Pembina sebanyak 61 persen hal tersebut termasuk dalam kriteria berkembang sesuai harapan
\end{abstract}

Kata Kunci : Keterampilan Intrapersonal, Pendidikan Anak Usia Dini, Anak Usia 5-6 Tahun

\begin{abstract}
This research is based on the importance of intrapersonal skills of children aged 5-6 years. Intrapersonal skills are the ability of individuals to understand themselves in other words, children are able to trust themselves, know their strengths and weaknesses, realize their emotions, and are proactive or responsible for their knowledge, feelings and actions. But when in the field the researchers found intrapersonal detection skills but were not based on an ideal theory. Thus the researcher took the focus of the study on Intrapersonal skills of children aged 5-6 years in the State Kindergarten Pembina. This study aims to measure, analyze, and describe the intrapersonal skills of children aged 5-6 years in TK Negeri Pembina Kota Tasikmalaya. Using descriptive methods with a quantitative approach. Data collection techniques through structured observation and integrated field notes in structured observation. The findings in this study that intrapersonal skills of children aged 5-6 years are in the category of developing as expected (BSH). Intrapersonal skills of children aged 5-6 years on the
\end{abstract}


aspect of self- confidence are in the category of developing according to expectations getting 62 Percent. Then in the aspect of self-assessment is in the category of developing according to expectations and gets 67 percent. Furthermore, the emotional awareness aspect of children aged 5-6 years is in the category of developing as expected with a percentage of 55 percent. the proactive or responsible aspects of children aged 5-6 years are in the category of developing according to expectations and the percentage gets 60 percent. Thus the percentage of intrapersonal skills of children aged 5-6 years in TK Negeri Pembina as much as 61 percent is included in the criteria of developing according to expectations.

Keywords: Intrapersonal Skills, Early Childhood Education, Children 5-6 Year

\section{PENDAHULUAN}

Anak adalah manusia kecil yang memiliki potensi yang harus dikembangkan oleh orang dewasa. kemudian Anak juga memiliki karakteristik yang berbeda dengan orang dewasa (sujiono, 2012). Sehingga Anak usia dini adalah sosok individu dalam tahap menjalani proses perkembangan dengan pesat dan fundamental bagi kehidupan selanjutnya. Anak Usia Dini adalah periode penting yang memberikan pengalaman awal dalam rentang kehidupan manusia.

Pengalaman awal yang diperoleh anak pada masa tersebut tidak akan terulang lagi maka dari itu pemberian rangsangan pendidikan pada anak yang tepat sangat diperlukan untuk memastikan bahwa setiap anak mencapai perkembangan yang optimal sehingga mereka mempunyai landasan yang kuat untuk menempuh pendidikan selanjutnya Program pendidikan untuk anak usia dini sering disebut PAUD.

PAUD adalah upaya yang diberikan oleh orang dewasa kepada anak usia 0 sampai 6 tahun dalam bentuk pendidikan baik secara formal, nonformal dan informal untuk dapat mengembangkan seluruh aspek perkembangan yang terdapat dalam diri anak yang akan memasuki jenjang pendidikan yang selanjutnya. Berdasarkan Permendikbud 146 tahun 2014 Pasal 5 menjelaskan bahwa "struktur kurikulum PAUD memuat program pengembangan yang mencakup nilai agama dan moral, fisik motorik, kognitif, bahasa, sosial emosional dan seni". salah satu program pengembangan yang harus di kembangkan ialah program pengembangan sosialemosional.

Dalam pengembangan sosial emosional terdapat beberapa aspek keterampilan yang harus dikembangkan anak. Menurut gandana (2012) menjelaskan "keterampilan sosial emosional terdapat aspek menjalin hubungan sosial yaitu intrapersonal dan interpersonal". Dalam diri anak banyak aspek yang perlu mendapat stimulasi agar dapat teraktualisasikan.

Keterampilan intrapersonal adalah salah satu keterampilan yang harus dikembangkan oleh anak disamping keterampilan yang lainnya. Keterampilan intrapersonal memungkinkan anak untuk menjalin komunikasi atau mengenali dirinya

sendiri. Baik dalam pikiran, perasaan maupun tindakannya. Tanpa memiliki keterampilan intrapersonal anak akan sulit mengendalikan dirinya sendiri bahkan anak akan berprilaku yang negatif. Seperti yang dijelaskan oleh Daniel Goleman (dalam rusmardiana, 2016 ) bahwa 'intrapersonal skill adalah kemampuan yang koleratif, tetapi terarah kedalam diri. Dengan demikian intrapesonal skill kunci menuju kemampuan diri dan kesuksesan individu dimasa depan'. dengan demikian keterampilan intrapersonal merupakan salah satu indikatot keberhasilan/kesuksesan anak dimasa depan.

Kenyataan yang terjadi dilapangan setelah dilakukan observasi di TK Negeri Pembina bahwa sudah dilakukannya deteksi terhadap keterampilan intrapersonal anak namun belum berlandaskan pada teori yang ideal. Serta guru belum berani melakukan pengembangan konsep pengukuran berlandas pada teori dan yuridis. Berdasarkan penelitian terdahulu belum adanya penelitian mengenai keterampilan intrapersonal anak usia 5-6 tahun di TK Negeri Pembina Kota Tasikmalaya, untuk mendeteksi keterampilan intrapersonal anak usia 5 sampai 6 tahun di TK Negeri Pembina berlandaskan teori secara ideal, peneliti melakukan observasi dan analisis di TK Negeri Pembina, serta penelitian ini berfokus pada keterampilan intrapersonal 5 sampai 6 tahun di TK Negeri Pembina Kota Tasikmalaya.

Anak usia dini adalah anak yang berada pada rentang usia 0-6 tahun dan merupakan sosok individu yang sedang menjalani suatu 
proses perkembangan dengan pesat dan fundamental bagi kehidupan selanjutnya (Sujiono, 2013, hlm. 6-7). Pada masa ini proses pertumbuhan dan perkembangan dalam berbagai aspek sedang mengalami masa yang cepat dalam rentang perkembangan hidup manusia.

\section{Dengan begitu Pengalaman awal}

landasan yang kuat untuk menempuh pendidikan selanjutnya. Program pendidikan untuk anak usia dini disebut dengan PAUD.

Menurut Permendikbud nomor 146 tahun 2014 Pasal 1 bahwa "Pendidikan anak usia dini, yang selanjutnya diksingkat PAUD merupakan suatu pembinaan yang ditujukan kepada anak sejak lahir sampai usia 6 tahun yang dilakukan melalui pemberian rangsangan pendidikan untuk membantu pertumbuhan dan perkembangan jasmani dan rohani agar anak memiliki kesiapan dalam memasuki pendidikan lebih lanjut".

Kemudian menurut Permendikbud

137 tahun 2014 pasal 10 menyebutkan bahwa "Lingkup perkembangan sesuai tingkat usia anak meliputi aspek nilai agama dan moral, fisik-motorik, kognitif, bahasa, sosialemosional, dan seni". dengan demikian aspek tersebut harus dikembangkan sejak dini melalui pendidikan. Salah satu aspek yang harus dikembangkan ialah aspek sosial emosional yang didalamnya mencakup kemampuan dalam menyadari diri sendiri dan bertanggung jawab terhadap tindakannya sendiri. Atau dengan kata lain disebut keterampilan intrapersonal.

Sesuai dengan pendapat Goleman (dalam rusmardiana, $2016 \mathrm{hlm}$ 97) menjelaskan bahwa intrapersonal skill adalah kemampuan yang korelatif, tetapi terarah dalam diri". Dengan demikian intrapersonal skill merupakan kunci menuju kemampuan diri dimasa depan. keterampilan intrapersonal merupakan kemampuan mengenali diri sendiri dengan mempercayai diri sendiri, menilai diri sendiri, menyadari emosi diri yang dirasakan serta berani tanggung jawab atas perbuatannya sendiri.

Sejalan dengan pendapat berapa ahli diantaranya menurut goleman (2010, hlm

42) bahwa intrapersonal merupakan kesadaran diri mengetahui kondisi sendiri, , kesukaan sumber daya dan intuisi. Kemudian menurut gardner (dalam krobo, 2014, hlm 27) intrapersonal merupakan bagian dari kecerdasan majemuk sebagai suatu yang diperoleh anak pada masa tersebut tidak akan terulang lagi maka dari itu pemberian rangsangan pendidikan pada anak yang tepat sangat diperlukan untuk memastikan bahwa setiap anak mencapai perkembangan yang optimal sehingga mereka mempunyai

kemampuan untuk mengenal

perasaan-perasaan seperti perasaan senang atau sedih.

Kemudian orang yang memiliki kekuatan intrapersonal terintegrasi sifat-sifat positif seperti teguh pendirian, jujur pada diri sendiri, introspektif, adil, berfikir panjang, kreatif, futuristik, disiplin, religius, dan hati-hati. Jika sifat-sifat tersebut keluar dari koridor yang sebenarnya dapat menyebabkan perilaku-perilaku negatif seperti egois, mementingkan diri sendiri, curang pada orang lain, berlebih-lebihan (over acting), dan sebagainya. Menurut Amstrong (dalam Musfiroh, 2018) 'awal masa anak-anak merupakan saat yang menentukan bagi perkembangan intrapersonal. Anak yang memperoleh kasih sayang, pengakuan, dorongan, dan tokoh panutan cenderung mampu mengembangkan konsep diri yang positif dan mampu membentuk citra diri sejati'.

Dengan demikian anak yang memiliki keterampilan intrapersonal yang tinggi anak tersebut akan memiliki pondasi yang kuat untuk mengembangkan kemampuan sosial emosinya. Hal tersebut bisa dikembangkan dalam pembelajaran terdapat beberapa aspek dalam keterampilan Intrapersonal diantaranya:

1) Aspek percaya diri pada keterampilan intrapersonal.

Goleman (2010) berpendapat bahwa "individu yang percaya diri ialah individu yang memiliki keyakinan harga diri dan kemampuan sendiri". Percaya diri ialah kemampuan individu untuk dapat memahami dan meyakini seluruh potensinya agar dapat dipergunakan dalam menghadapi penyesuaian diri dengan lingkungan hidupnya. Dengan demikian anak yang 
percaya diri biasanya mempunyai inisiatif, kreatif, dan optimis terhadap masa depan, berpikir positif, menganggap semua permasalahan pasti ada jalan keluarnya. Anak yang percaya diri meliputi percaya diri terhadap pengetahuan, perasaan dan tindakan,

2) Aspek Penilaian diri pada keterampilan intrapersonal

Penilaian diri ialah kemampuan individu untuk menyadari kekuatan dan kelemahan dirinya. Dengan demikian Jika seorang individu dapat menilai dirinya

sendiri, maka otomatis ia akan selalu berintrospeksi sehingga dirinya akan terus berkembang untuk lebih baik serta mengetahui kekuatan dan batasbatas diri sendiri. Sesuai dengan pendapat Goleman (2010, hlm 42) bahwa " penilaian diri yang teliti mengetahui kekuatan dan batasan diri”. Penilaian diri meliputi penilaian diri terhadap pengetahuan, perasaan dan tindakan.

3) Aspek kesadran emosi diri pada ketrampilan intrapersonal

Menurut Goleman (2010, Hlm 42) "kesadaran emosi diri merupakan kemampuan mengenali emosi diri sendiri serta mengetahui efeknya". Dengan demikian Kesadaran emosi diri adalah kemampuan untuk mengenali dan memahami perasaan sendiri sewaktu perasaan itu terjadi dan mengetahui efek yang akan timbul. Kesadaran emosi diri meliputi pengetahuan persaan dan tindakan.

4) Aspek proaktif pada keterampilan intrapersonal

Proaktif adalah kemampuan individu untuk bertanggung jawab atas kehidupannya sendiri. Segala perbuatan dan tingkah laku covey (dalam machrus, 2005) berpendapat bahwa 'sikap proaktif yaitu memilih sikap $N P=$

Keterangan :

$S M$

$\times 100$

tahun meliputi proaktif terhadap pengetahuan, perasaan dan tindakaanya. Dengan demikian proaktif merupakan kemampuan individu bertanggung jawab atas pengetahuan, perasaan serta tindakan yang dilakukannya. yang kita lakukan berasal dari inisiatif kita sendiri (olivia, 2018) dalam bertanggung jawab biasanya seseorang akan melakukan tindakan dengan sebaik mungkin sesuai dengan etika peraturan demi tegaknya perasaan memenuhi kewajiban. Setelah itu

kuantitatif. Pendekatan kuantitatif adalah penelitian dimana data berupa angka dan dianalisis menggunakan statistik. Populasi yang digunakan dalam penelitian ini adalah anak usia 5-6 tahun di TK Negeri Pembina Kota Tasikmalaya. Jumlah sampel yang diteliti adalah 4 orang anak dari 15 orang anak di Kelas B2 TK Negeri Pembina Kota Taikmalaya. Dalam penelitian ini, peneliti menggunakan teknik pengumpulan data dengan observasi, catatan lapangan yang terintegrasi dalam observasi terstruktur dan dokumentasi. Analisis data dilakukan pada hasil data yang terdapat berdasarkan instrumen observasi yang dilakukan oleh observer dengan memberikan tanda checklist pada skala kemunculan yang sesuai. Adapun cara menetukan rata-rata (mean) mengacu pada lutfi nur (2016, hlm 59) sebagai berikut:

$$
x=\sum x i
$$

Keterangan:

$\not$ Nilai rata-rata

$X i=$ skor yang

didapat $\mathrm{N}=$

Banyaknya data

$\Sigma=$ Menyatakan jumlah

1) Menentukan persentase

keterampilan intrapersonal

Berikut ini cara menentukan

persentase mengacu pada Ngaalim

Purwanto (2006:102) dengan

menggunakan rumus :

$R$

\section{METODOLOGI PENELITIAN}

Metode penelitian ini yaitu metode penelitian deskriptif. Menurut Sugiyono (dalam Rustandi, D.F. 2017) menjalaskan bahwa metode deskriptif adalah metode yang dimaksudkan untuk mencari informasi, memaparkan apa yang sedang terjadi dilapangan. Penelitian ini disusun dengan menggunakan pendekatan penelitian bertanggung jawab atas sikap dan perilakunya'. Proaktif dalam keterampilan intrapersonal usia 
5-6

$\mathrm{NP}=$ Nilai persen yang dicari

$\mathrm{R}=$ Skor mentah yang diperoleh siswa

$\mathrm{SM}=$ Skor Maksimal ideal dari tes yang bersangkutan

\section{HASIL DAN PEMBAHASAN}

Penelitian ini bertujuan untuk mengukur, menganalisis serta mendeskripsikan keterampilan intrapersonal anak usia 5-6 tahun di TK Negeri Pembina. berdasarkan hasil temuan yang telah dilakukan oleh peneliti diperoleh temuan keterampilan intrapersonal usia 5-6 tahun di TK Negeri Pembina diantaranya:

Keterampilan Intrapersonal anak usia 5-6 tahun pada aspek percaya diri di TK Negeri Pembina termasuk dalam kriteria BSH (Berkembang Sesuai Harapan). Disamping itu, rata-rata yang didapat oleh masing-masing anak dalam kriteria berkembang sesuai harapan (BSH) dengan persentase sesuai dengan pendapat goleman (2010) bahwa "individu yang percaya diri ialah individu yang memiliki keyakinan harga diri dan kemampuan sendiri”. indikator yang tercapai pada anak usia 5-6 tahun diataranya percaya diri terhadap pengetahuan nya. Percaya diri terhadap perasaannya dan percaya diri terhadap tindakannya. Meskipun demikian terdapat beberapa item dalam indikator tersebut yang belum muncul. Hal ini sejalan dengan pendapat safaria (2005).menyatakan bahwa "Semakin banyak input positif yang didapatkan anak, maka akan semakin positif identitas diri anak. penerimaan serta dukungan dari orang tua termasuk lingkungan sebayanya. Anak akan semakin percaya diri sehingga hal ini akan meningkatkan harga diri anak".

1. Keterampilan Intrapersonal anak usia 5-6 tahun di TK Negeri Pembina pada aspek Penilaian diri termasuk dalam kriteria BSH (Berkembang Sesuai Harapan).hal tersebut

2. sesuai dengan pendapat Goleman (2010, hlm 42) bahwa " penilaian diri yang teliti mengetahui kekuatan dan batasan diri". Meskipun demikian penilaian diri yang didapat oleh masing-masing anak berada pada kategori berkembang sangat baik (BSB) 25 persen, berkembang sesuai harapan (BSH) 25 persen dan mulai berkembang (MB) 50 persen.

3. Keterampilan Intrapersonal anak usia 5-6 tahun pada aspek kesadaran emosi diri termasuk dalam kategori berkembang sesuai harapan (BSH). hal tersebut sesuai dengan pendapat Goleman (2010, Hlm

42) "kesadaran emosi diri merupakan kemampuan mengenali emosi diri sendiri serta mengetahui efeknya". Sedangkan Masing-masing anak mendapat rata-rata yang termasuk dalam kategori berkembang sesuai harapan $(\mathrm{BSH}) 75$ persen dan mulai berkembang (MB) 25 persen.

4. Keterampilan Intrapersonal anak usia 5-6 tahun pada aspek proaktif termasuk

dalam kategori berkembang sesuai harapan (BSH). Proaktif adalah kemampuan individu untuk bertanggung jawab atas kehidupannya sendiri. Segala perbuatan dan tingkah laku yang dilakukan berasal dari inisiatif kita sendiri (olivia, 2018). Hasil dari penelitian yang telah dilakukan mendeteksibahwa keterampilan intrapersonal anak usia 5-6 tahun di TK Negeri Pembina termasuk dalam kategori berkembang sesuai harapan (BSH). hal tersebut sesuai dengan pendapat Daniel Goleman (dalam rusmardiana, 2016) bahwa "intrapersonal skill merupakan kemampuan yang koleratif, namun terarah dalam diri untuk menempuh kehidupan secara efektif ysng merupakan akses menuju perasaan- perasaan diri dan kemampuan untuk membedakan perasaanperasaan tersebut serta memanfaatkannya untuk menuntun tingkah laku". Dengan demikian keterampilan intrapersona merupakam kunci untuk kemampuan diri seseorang untuk bertingkah laku yang baik.

\section{SIMPULAN}

Berdasarkan hasil penelitian yang telah dilakukan di TK Negeri Pembina terkait deteksi keterampilan intrapersonal anak usia 4-5 tahun, peneliti dapat mengambil simpulan sebagai berikut:

5. Keterampilan Intrapersonal anak usia 5-6 tahun di TK Negeri Pembina termasuk dalam kriteria BSH (Berkembang Sesuai Harapan).

6. Keterampilan Intrapersonal anak usia 5-6 tahun di TK Negeri Pembina pada aspek Percaya diri termasuk dalam kriteria BSH (Berkembang Sesuai Harapan)..

7. Keterampilan Intrapersonal anak usia 5-6 
tahun pada aspek penilaian diri termasuk dalam kategori berkembang sesuai harapan (BSH).

8. Keterampilan Intrapersonal anak usia 5-6 tahun pada aspek kesadaran emosi diri termasuk dalam kategori berkembang sesuai harapan (BSH).

9. Keterampilan Intrapersonal anak usia 5-6 tahun pada aspek proaktif atau bertanggung jawab termasuk dalam kategori berkembang sesuai harapan $(\mathrm{BSH})$

\section{DAFTAR PUSTAKA}

Musfiroh, T. (2018). Pengembangan Kecerdasan Majemuk. Tanggerang Selatan: Universitas Terbuka

Nur, L. (2016) . Modul Statistika Deskriptif. Tasikmalaya: UPI Tasikmalaya. University [Online]

Prastiwi, W.Y. (2011). Pengembangan Soft skill, Hard Skill dan Life Skill Peserta Didik dalam Menghadapi Era Globalisasi.

Rusmardiana, A. (2016). Soft Skills terhadap Karakter Siswa Sekolah Dasar, jurnal : Faktor jurnal ilmiah kependidikan, 3, 97-104.

Safaria. (2005). Interpersonal Intelegence (Metode Pengembangan Kecerdasan Anak). Yogyakarta : Amara Books

Sugiono. (2016). Metode Penelitian Kuantatif, Kualitatif dan $R \& D$. Bandung :Alfabeta

Sujiono, Y. N. (2009). Konsep Dasap Pendidikan Anak Usia Dini. Jakarta: PT Indeks.

Suryana, S. \& Latiana, L. (2013). Character Education Model in Early chilhood education studies. Indonesian journal of early chilhood education studies 2, 45-57.

Wahyudi, D. (2011). Pembelajaran IPS Berbasis Kecerdasan Intrapersonal Interpersonal dan Eksistensial. Jurnal : edisi khusus No.1, 33-45.

Yaumi, M. \& Ibrahim, N. (2013). Pembelajran Berbasis Kecedasan Jamak (Multiple Intelegences). Jakarta : Kencana Prebanada Grou 